\title{
Research Regarding Crude Chemical Composition and Heavy Metal Content of Some Ecological Forages Utilised in Dairy Cows Nourishment
}

\author{
GHERASIM NACU ${ }^{1}$, NADIA AIOANEI ${ }^{1}$, IOAN MIRCEA POP ${ }^{1}$, DANIEL SIMEANU ${ }^{*}$, \\ PAUL-CORNELIU BOISTEANU ${ }^{1}$, VASILE VINTILA ${ }^{2 *}$, OLIMPIA MINTAS ${ }^{3 *}$, \\ CRISTINA SIMEANU ${ }^{1}$, BOGDAN-VLAD AVARVAREI ${ }^{1}$ \\ ${ }^{1}$ University of Agricultural Sciences and Veterinary Medicine from Iasi, Faculty of Animal Sciences, 8 Mihail Sadoveanu \\ Alley, 700489, Iasi, Romania \\ ${ }^{2}$ Cattle Breeding Research Station from Dancu, 9 Iasi - Ungheni Road, 707252, Iasi, Romania \\ ${ }^{3}$ University of Oradea, Faculty of Environmental Protection, 1 University Street, 410087, Oradea, Romania
}

\begin{abstract}
Knowing the importance of utilised food for milk obtaining, in the current paper we determine the chemical composition of a natural meadow and green mass alfalfa cultivated in ecological and conventional systems, utilised for dairy cows feeding. Were analysed the content in: dry matter DM (\%), crude ash C.Ash (\%), organic substance OS (\%), crude protein CP (\%), crude cellulose CC (\%), non-nitrogenous extractive substances NES (\%), neutral detergent fibre NDF (\%), acid detergent fibre ADF (\%), Ca (\%), P (\%), heavy metals (Pb, Cd, Zn, Cu-ppm), nitrates, nitrites and pesticides. Analysis were realised in two consecutive production years, for each indicator being made 5 determinations. Samples gathering and analysis were effectuated in according with standards and enshrined working methods. Differences between crude chemical composition of forages obtained in ecological system and the ones obtained by conventional agriculture had statistical significance (from significant $-p \leq 0.05$ - to very significant $-p \leq 0.001$ ) for the majority of indicators. Differences between those two production systems were insignificant only for crude fat (both forages), crude cellulose (alfalfa), non-nitrogenous extractive substances (both forages) and for acid detergent fibre (alfalfa). Both forages were safety regarding pollutants (heavy metals, nitrites, nitrates and pesticides), existing however statistically differences between those two production systems, in the favour of ecological one.
\end{abstract}

Keywords: chemical composition, forages, ecological, heavy metals, pollutants

\section{Introduction}

Cow milk is a food with high nutritional value being rich in minerals, vitamins, proteins, fats and carbohydrates [1], being recommended for daily consumption [2], both for adults and as well as for younger [3, 4]. Obtaining of ecological cow milk suppose utilisation in cows' nourishment of fodders resulted from ecological agriculture [5]. Ecological agriculture means renouncing at chemical fertilizers for avoiding accumulation of nitrites and nitrates, replacement of pesticides with ecological products and methods for combat of pest and ill diseases, avoiding of contamination with heavy metals $(\mathrm{Pb}, \mathrm{Cd}, \mathrm{Cu}, \mathrm{Zn})$, limitation of using of antibiotics for treatments [5].

Practice of ecological agriculture assure maintain of flora and fauna biodiversity [6], maintain of soils' fertility [7], welfare of animals and humans [5-8]. Contents in pesticides, heavy metals, nitrites, nitrates, antibiotics residuum represent relevant indicators for pollution level and for the quality of ecological products.

\footnotetext{
*email:dsimeanu@uaiasi.ro;vasilevintilais@yahoo.com,buzasiu@yahoo.com
} 
Pesticides are used for pest control and are characterized by accumulation in environment, especially in alimentary chain [9]. Those ones pass from soil to plants [10] and reach the final consumer through trophic chain $[11,12]$. Pesticides could reach by trophic chain also in milk [13, 14]. Effects on humans are diverse. Could cause immediate reactions (headaches, injuries of eyes, stomach aches) [15] as well as metabolic disorders [16], cancer, asthma, diabetes [17]. Possibility that pesticides to reach into organic foods are much reduced [18]. Biological value of ecological foods, and especially of milk, is superior to the conventional ones [19].

Heavy metals have an important role in regulation of some functions of organism but can also disturb them by toxic effects. Contamination sources of fodders with heavy metals are various: mineral fertilizers, irrigation water, organic fertilizers, amendments, cars' aerosols, thermal combustion based on coal, different industries [20,21]. Irrigation of crops with waste waters could determine apparition of heavy metals in forages and after that in milk [22]. Numerous studies aimed the dosage of heavy metals in plants [23-26], aliments - including milk [27]. Heavy metals are accumulated in animal organisms [28]. At humans could cause chronically diseases [29], neurodegenerative diseases [30], and children being very vulnerable [31].

Nitrates are essential elements for plants' developing. Some studies show that conventional products with vegetal origin have higher nitrate content in comparison with the ones obtained in ecological system [32]. Many studies shown that products obtained from ecological agriculture have a lower pollution risk in comparison with the one obtained by conventional agriculture [33-35], being more safety for humans' nourishment.

In this context of knowing the risks which are related to some pollutants (possibly being into forages respectively foods) on human's health, ecological agriculture represent an alternative for obtaining of clean and safety foods [36].

Because quality of food products depends on quality of raw material and this one by the quality of feed administrated to animals, by the current paper we aimed to determine the chemical composition of green mass alfalfa and natural meadow obtained in ecological system, frequently utilized in dairy cows' nourishment and to show the possible differences between those two systems for producing of forages.

\section{Materials and methods}

Chemical composition for natural meadow was determined at the beginning of flowering stage and for green mass alfalfa at the beginning of budding. Samples gathering for laboratory analysis were realized in accordance with the nowadays standards [37, 38], and for each element being made 5 determinations.

Dry matter content (DM) was determined by drying of samples at $105^{\circ} \mathrm{C}$ for 6 hours, into a ESAC 50 type electric drying oven. Operation was repeated till was obtained a constant mass, in according with standard SR ISO 6496:2001 [39, 40] and SR ISO 712:2010 [41, 42].

Crude ash (C.Ash) was determined in according with standard ISO 2171:2010 [43] and AOAC 1990 [44], by calcinations of samples at $550^{\circ}$ C. It was used a Superterme STC 611.06 calcinations oven.

Organic substance content (OS) was determined as difference between DM and C.Ash [45].

Crude protein (CP) was determined using Kjeldahl method (ISO 5983-1:2006) [46, 47].

Determination of crude fat $(\mathrm{CF})$ was realized by extraction with organic solvents (petroleum ether) using indirect Soxhlet method, in according with ISO 6492:2001 [48, 49]. It was utilized the Solvent Extractor SER 148-VELP device.

Determination of crude cellulose (CC) was realized in according with SR EN ISO 6865:2002 [50, 51]. It was utilized the semiautomatic method for fibres' extraction VELP FIVE 6, and the reagents were: hydrochloric acid $0.5 \mathrm{~mol} / \mathrm{L}$, sulphuric acid $0.13 \mathrm{~mol} / \mathrm{L}$, acetone, $\mathrm{n}$-octanol - antifoaming agent, acetone. 
Determination of nutritional parameters helped us to calculate the quantity of non-nitrogenous extractive substances (NES) using the following formula [52-54]:

$\mathrm{NES} \%=\mathrm{OS} \%-(\mathrm{CP} \%+\mathrm{CF} \%+\mathrm{CC} \%)$

Determination of fibres content by titration with neutral detergent was realized in according with standard SR EN ISO 16472:2006 [55]. Determination of acid detergent fibre was realized respecting standard SR EN ISO 13906:2008 [56].

Content in $\mathrm{P}$ was determined by spectrophotocolorimetric method using molybdovanadate reagent at a wave length of $430 \mathrm{~nm}$ at Shimadzu Uv Mini 1240 spectrophotometer. Calibration curve was drawn in 5 points by preparation from standard phosphorous solution of some solutions with different phosphorous concentrations: 5, 10, 15, 20, 25, 30 and $40 \mathrm{mg} / \mathrm{L}[57,58]$.

$\mathrm{Ca}$ content was determined by using of atomic absorption spectrometry method in according with SR EN ISO 6869:2002 [59]. It was used an AA-6300 Shimadzu atomic absorption spectrometer with flame, at a wave length of $422.6 \mathrm{~nm}$, in comparison with the lantan-cesium control solution. Calibration curve was designed in 3 points by preparation from calcium standard solution of some solutions with different concentrations: $0.5,1.5,2.0 \mathrm{mg} / \mathrm{L}$.

Heavy metals content $(\mathrm{Pb}, \mathrm{Cd}, \mathrm{Cu}$ and $\mathrm{Zn}$ ) was determined in according with SR EN 14082:2003 [60], AOAC, 1990 [44], by using the atomic absorption spectrometric method (AAS) on a GBCAVANTA type spectrometer. Calibration curves for plumb were realized in 5 points $(0.5 ; 1 ; 2.5 ; 5$ and $7.5 \mathrm{ppm})$, for cadmium in 5 points $(0.2 ; 0.5 ; 1 ; 1.5$ and $2 \mathrm{ppm})$, for copper in 3 points $(1 ; 2$ and $4 \mathrm{ppm})$ and for zinc in 4 points $(1 ; 2 ; 3$ and $4 \mathrm{ppm})$. Wave lengths at which were determined the concentrations of metals were as follows: $\mathrm{Pb}, \lambda=217 \mathrm{~nm} ; \mathrm{Cd}, \lambda=228.8 \mathrm{~nm} ; \mathrm{Cu}, \lambda=324.7 \mathrm{~nm} ; \mathrm{Zn}, \lambda=213.9 \mathrm{~nm}$ [61].

Determination of organo-chlorinated and organo-phosphoric pesticides residuum was realized by gas-chromatography method, in according with standard SR EN ISO 14181:2001 [62], SR EN ISO 14182:2001 [63] for nutrients. As etalon solution was utilized a mix of 80 organo-chlorinated and organo-phosphoric pesticides.

Nitrates and nitrites were determined in according with SR 13175:1993 [64]. Method consisted in extraction of nitrites from the analyzing sample by deproteinization of extract and highlighting through a coloration reaction in red nuances of nitrites, with sulfanilamide and $\mathrm{N}$-(1-naphthyl) ethylenediamine dihydrochloride. Photocolorimetry was realized at a wave length of $538 \mathrm{~nm}$. Determination of nitrates was realized by reduction of those ones at nitrites in the presence of cadmium followed by a colouring reaction and colorimetry. It was used the spectrophotometer Shimadzu Uv Mini 1240 [61].

The obtained data were statistically processed and interpreted. Were calculated the position and variation estimators (arithmetic mean, variance, standard deviation standard deviation of mean and variation coefficient). Establishing of difference signification between those two productions systems were raised by using the statistic software IBM SPSS 21.0 through cu Tukey test with two variables, T-Test (2-tailed) [61].

\section{Results and discussions}

Content in DM of natural meadow gathered at the beginning of flowering from conventional system was $16.81 \%$ in $1^{\text {st }}$ year and $15.31 \%$ in $2^{\text {nd }}$ year, values under the limit of the ones cited in literature, of $17.2 \%$ [52, 65] $\div 24.12 \%$ [66]. The mean values obtained for samples from ecological system $\left(25.72 \%\right.$ in $1^{\text {st }}$ year and $22.58 \%$ in $2^{\text {nd }}$ year $)$ exceed the superior limit of the mentioned interval. The differences between those two systems were very significant (Table 1).

The mean values determined for content of green mass alfalfa in DM, before budding, both for samples gathered from ecological system $(20.13 \%$ and $25.8 \%)$, as well as for the ones gathered from conventional system (21.89\% and $26.32 \%$ ), are placed above the maximum limit of the interval which was founded in literature which is $14.4 \%$ [65] and $15 \%$ [67]. Statistical differences between those two systems were insignificant for the both research years.

For quantity of C.Ash from natural meadow, was observed that the mean values of $11.58 \%$ and 
$10.78 \%$ for the analysed samples from conventional system in those two consecutive years exceeded the maximal interval value of $9.4 \%$ [68] and $10.3 \%$ [69], and the values of $6.07 \%$ and $7.02 \%$ obtained for ecological system are under the minimal value of the mentioned interval. Statistical differences between those two systems were very significant for the both research years.

Content in C.Ash of green mass alfalfa had mean values which were into variation limit of 8\% [70] and $12.9 \%$ [65], both for samples gathered from ecological system and as well as for the ones gathered from conventional system. Statistical differences between those two systems were very significant for the both research years.

Table 1. Results on the chemical composition of ecological and conventional forages (\% DM)

\begin{tabular}{|c|c|c|c|c|c|c|c|c|c|c|}
\hline \multirow{3}{*}{\multicolumn{2}{|c|}{ Specification }} & \multirow{3}{*}{$\mathrm{n}$} & \multicolumn{4}{|c|}{ Natural grassland } & \multicolumn{4}{|c|}{ Alfalfa green } \\
\hline & & & \multicolumn{2}{|c|}{$1^{\text {st }}$ year } & \multicolumn{2}{|l|}{$2^{\text {nd }}$ year } & \multicolumn{2}{|l|}{$1^{\text {st }}$ year } & \multicolumn{2}{|l|}{$2^{\text {nd }}$ year } \\
\hline & & & $\mathrm{X} \pm \mathrm{s}_{\mathrm{x}}$ & $\mathrm{V} \%$ & $\mathrm{X} \pm \mathrm{s}_{\mathrm{x}}$ & $\mathrm{V} \%$ & $\mathrm{X} \pm \mathrm{s}_{\mathrm{X}}$ & V\% & $\mathrm{X} \pm \mathrm{s}_{\mathrm{x}}$ & $\mathrm{V} \%$ \\
\hline \multirow[b]{2}{*}{ DM\% } & Conv. & 5 & $16.81 \pm 0.53^{\mathrm{a}}$ & 7.03 & $15.31 \pm 0.56^{\mathrm{a}}$ & 8.17 & $21.89 \pm 0.82^{\mathrm{a}}$ & 8.33 & $26.32 \pm 0.86^{\mathrm{a}}$ & 2.41 \\
\hline & Eco. & 5 & $25.72 \pm 1.13^{\mathrm{d}}$ & 9.81 & $22.58 \pm 1.04^{\mathrm{d}}$ & 10.32 & $20.13 \pm 0.28^{\mathrm{a}}$ & 3.10 & $25.8 \pm 0.28^{\mathrm{a}}$ & 7.29 \\
\hline \multirow[b]{2}{*}{ C.Ash } & Conv. & 5 & $11.58 \pm 0.31^{\mathrm{a}}$ & 6.05 & $10.78 \pm 0.36^{\mathrm{a}}$ & 7.51 & $8.01 \pm 0.10^{\mathrm{a}}$ & 2.87 & $11.12 \pm 0.08^{\mathrm{a}}$ & 4.81 \\
\hline & Eco. & 5 & $6.07 \pm 0.14^{\mathrm{d}}$ & 5.20 & $7.02 \pm 0.16^{\mathrm{d}}$ & 4.99 & $10.37 \pm 0.26^{\mathrm{d}}$ & 5.54 & $12.68 \pm 0.27^{\mathrm{d}}$ & 1.71 \\
\hline \multirow{2}{*}{ OS } & Conv. & 5 & $81.31 \pm 1.98^{\mathrm{a}}$ & 5.46 & $80.67 \pm 2.09^{\mathrm{a}}$ & 5.79 & $86.18 \pm 0.96^{\mathrm{a}}$ & 2.50 & $82.12 \pm 1.05^{\mathrm{a}}$ & 2.15 \\
\hline & Eco. & 5 & $89.32 \pm 0.92^{\mathrm{c}}$ & 2.31 & $87.37 \pm 0.95^{\mathrm{b}}$ & 2.43 & $81.65 \pm 0.82^{\mathrm{c}}$ & 2.26 & $81.56 \pm 0.78^{\mathrm{a}}$ & 2.85 \\
\hline \multirow{2}{*}{$\mathrm{CP}$} & Conv. & 5 & $11.43 \pm 0.54^{\mathrm{a}}$ & 10.55 & $10.24 \pm 0.60^{\mathrm{a}}$ & 13.08 & $26.97 \pm 0.29^{\mathrm{a}}$ & 2.43 & $28.58 \pm 0.32^{\mathrm{a}}$ & 2.52 \\
\hline & Eco. & 5 & $8,04 \pm 0,21^{\mathrm{d}}$ & 5.75 & $7.83 \pm 0.19^{\mathrm{c}}$ & 5.36 & $25.21 \pm 0.30^{c}$ & 2.65 & $26.81 \pm 0.33^{\mathrm{c}}$ & 3.02 \\
\hline \multirow{2}{*}{$\mathrm{CF}$} & Conv. & 5 & $2.51 \pm 0.12^{\mathrm{a}}$ & 13.11 & $1.97 \pm 0.12^{\mathrm{a}}$ & 13.20 & $2.03 \pm 0.14^{\mathrm{a}}$ & 14.88 & $2.19 \pm 0.03^{\mathrm{a}}$ & 5.50 \\
\hline & Eco. & 5 & $2.76 \pm 0.09^{\mathrm{a}}$ & 7.11 & $2.25 \pm 0.11^{\mathrm{a}}$ & 10.67 & $2.09 \pm 0.02^{\mathrm{a}}$ & 2.57 & $2.5 \pm 0.16^{\mathrm{a}}$ & 14.00 \\
\hline \multirow{2}{*}{$\mathrm{CC}$} & Conv. & 5 & $25.94 \pm 0.97^{\mathrm{a}}$ & 8.36 & $29.31 \pm 0.99^{\mathrm{a}}$ & 8.40 & $22.15 \pm 0.64^{\mathrm{a}}$ & 6.43 & $23.46 \pm 0.61^{\mathrm{a}}$ & 6.45 \\
\hline & Eco. & 5 & $30.02 \pm 0.83^{b}$ & 6.21 & $32.02 \pm 0.86^{\mathrm{c}}$ & 6.03 & $20.73 \pm 0.61^{\mathrm{a}}$ & 6.57 & $21.56 \pm 0.62^{\mathrm{a}}$ & 5.84 \\
\hline \multirow{2}{*}{ NES } & Conv. & 5 & $41.93 \pm 2.86^{\mathrm{a}}$ & 15.27 & $30.88 \pm 3.03^{\mathrm{a}}$ & 20.01 & $32.86 \pm 1.37^{\mathrm{a}}$ & 9.43 & $28.89 \pm 1.53^{\mathrm{a}}$ & 11.31 \\
\hline & Eco. & 5 & $43.50 \pm 1.27^{\mathrm{a}}$ & 5.84 & $45.27 \pm 1.23^{\mathrm{c}}$ & 6.08 & $35.78 \pm 1.38^{\circ}$ & 8.40 & $29.69 \pm 1.75^{\mathrm{a}}$ & 5.84 \\
\hline \multirow{2}{*}{$\mathrm{NDF}$} & Conv. & 5 & $53.63 \pm 1.20^{\mathrm{a}}$ & 5.01 & $54.42 \pm 1.66^{\mathrm{a}}$ & 6.82 & $39.06 \pm 0.50^{\mathrm{a}}$ & 2.87 & $40.01 \pm 0.55^{\mathrm{a}}$ & 8.39 \\
\hline & Eco. & 5 & $64.43 \pm 1.14^{\mathrm{d}}$ & 3.98 & $65.23 \pm 1.11^{\mathrm{d}}$ & 3.80 & $34.91 \pm 1.29^{\mathrm{b}}$ & 8.26 & $35.41 \pm 1.33^{\mathrm{b}}$ & 3.07 \\
\hline \multirow{2}{*}{$\mathrm{ADF}$} & Conv. & 5 & $25.70 \pm 1.17^{\mathrm{a}}$ & 10.21 & $26.31 \pm 1.14^{\mathrm{a}}$ & 9.73 & $23.41 \pm 0.70^{\mathrm{a}}$ & 6.69 & $23.75 \pm 0.75^{\mathrm{a}}$ & 10.51 \\
\hline & Eco. & 5 & $30,07 \pm 0,84^{\mathrm{c}}$ & 6.27 & $31.04 \pm 0.90^{\mathrm{b}}$ & 6.48 & $21.55 \pm 0.96^{\mathrm{a}}$ & 10.01 & $22.65 \pm 1.06^{\mathrm{a}}$ & 7.03 \\
\hline \multirow{2}{*}{$\mathrm{Ca}$} & Conv. & 5 & $0.59 \pm 0.20^{\mathrm{a}}$ & 7.09 & $0.561 \pm 0.02^{\mathrm{a}}$ & 6.79 & $1.351 \pm 0.013^{\mathrm{a}}$ & 2.10 & $1.408 \pm 0.014^{\mathrm{a}}$ & 2.20 \\
\hline & Eco. & 5 & $0.68 \pm 0.25^{\mathrm{c}}$ & 8.02 & $0.701 \pm 0.02^{\mathrm{d}}$ & 6.99 & $1.787 \pm 0.04^{\mathrm{d}}$ & 4.34 & $1.807 \pm 0.032^{\mathrm{d}}$ & 3.78 \\
\hline \multirow[b]{2}{*}{$\mathrm{P}$} & Conv. & 5 & $0.30 \pm 0.02^{\mathrm{a}}$ & 11.40 & $0.270 \pm 0.01^{\mathrm{a}}$ & 11.03 & $0.311 \pm 0.012^{\mathrm{a}}$ & 8.50 & $0.351 \pm 0.010^{\mathrm{a}}$ & 6.26 \\
\hline & Eco. & 5 & $0.355 \pm 0.017^{\mathrm{c}}$ & 10.64 & $0.383 \pm 0.016^{\mathrm{d}}$ & 9.13 & $0.251 \pm 0.022^{\mathrm{b}}$ & 19.27 & $0.271 \pm 0.023^{b}$ & 19.17 \\
\hline
\end{tabular}

Different exponents for the same indicator and year, show significant differences for mono-factorial analysis of variance (ANOVA): $\mathrm{p} \leq 0.05$ for ${ }^{\mathrm{ab}}, \mathrm{p} \leq 0.01$ for ${ }^{\mathrm{ac}}, \mathrm{p} \leq 0.001$ for ${ }^{\text {ad }}$

For value of content in OS was observed that at natural meadow, mean values of $81.31 \%$ and $80.67 \%$, founded for samples gathered from conventional system and respectively $89.32 \%$ and $87.37 \%$ founded at the samples gathered form ecological system were under the minimal limit of the interval cited by literature, 89.7\% [69] and 90.7\% [68]. Statistical differences between those two systems were distinct significant for $1^{\text {st }}$ year and significant for $2^{\text {nd }}$ year.

Mean values for content in OS of green mass alfalfa were of $86.18 \%$ and $82.12 \%$ for samples gathered from conventional system and $81.65 \%$ and $81.56 \%$ for the ones gathered from ecological system and the statistical differences between those two systems were distinct significant for $1^{\text {st }}$ year and insignificant for $2^{\text {nd }}$ year of production.

Content of natural meadow in CP, with values of $8.04 \%$ and $7.83 \%$ for samples gathered from ecological system and $11.43 \%$ and $10.24 \%$ for the ones from conventional system are under the inferior limit of the interval from literature 13.3\% [52,65] and 16.2\% [66]. Statistical differences between those two systems were distinct significant for the samples analysed in the $1^{\text {st }}$ year and distinct significant for the ones from $2^{\text {nd }}$ year.

Content in CP of green mass alfalfa before budding, with mean values of $25.21 \%$ and $26.81 \%$ for samples gathered from ecological system were into limits founded in literature 19\% [70] and $25.6 \%$ [67], while the mean values established for the samples gathered from conventional system $(26.97 \%$ and $28.58 \%$ ) exceeded the maximal limit of the above mentioned interval, statistical differences 
between those two systems being distinct significant for both research years.

In case of CF for natural meadows, the identified mean values of $2.51 \%$ and $1.97 \%$ for analysed samples from conventional system and $2.76 \%$ and $2.55 \%$ for the ones analysed from ecological system, are into the limits presented by literature 1.9\% [68] and 4.5\% [69]. It was observed that statistical differences between those two systems were insignificant for both years of study.

The mean values established for content in CF of green mass alfalfa were of $2.03 \%$ and $2.19 \%$ for samples gathered from conventional system and $2.09 \%$ and $2.75 \%$ for the ones gathered from ecological system. Also in this case statistical differences between those two systems were insignificant for both years of study.

Interval of $27.2 \% \mathrm{CC}[65,67]$ and $31 \% \mathrm{CC}$ [68] included mean values established in our own research for CC content of natural meadow: $25.94 \%$ and $29.31 \%$ for samples gathered from conventional system respectively $30.02 \%$ in the $1^{\text {st }}$ year. Value of $32.02 \% \mathrm{CC}$ founded at samples analysed from ecological system was superior to the maximal limit from literature. The statistical differences between those two systems were distinct significant.

For content in CC of green mass alfalfa before budding, the values established for samples gathered from ecological system as well as the ones gathered from conventional system was into variation limit of $20.1 \%$ [65] and $28.0 \%$ [70]. Statistical differences between those two systems, for this parameter, were insignificant for both research years.

Non-nitrogenous extractive substance from natural meadow was between $41.93 \%$ and $30.88 \%$, for the samples gathered from conventional system and between $48.50 \%$ and $45.27 \%$ for the ones gathered from ecological system. Statistical differences between those two systems were insignificant for $1^{\text {st }}$ year and distinct significant for $2^{\text {nd }}$ year.

In case of alfalfa NES was between $32.86 \%$ and $28.89 \%$, for the samples gathered from conventional system and between $35.78 \%$ and $29.69 \%$ for the ones from ecological system, statistical differences between those two systems being significant for $1^{\text {st }}$ year and insignificant for $2^{\text {nd }}$ year.

Mean values of $64.43 \%$ and $65.23 \%$ NDF from natural meadow, for samples gathered from ecological system are above the maximal limit of the interval founded in literature 50.1\% NDF [68] and 58.8\% NDF [69], and the values of 53.63\% NDF and 54.42\% NDF for samples gathered from ecological system are into the mentioned. Statistical differences between those two productions systems being very significant.

Mean values for NDF from alfalfa oscillated between $39.06 \%$ and $40.01 \%$ for the analysed samples from conventional system and between $34.9 \%$ and $35.41 \%$, for the ones from ecological system. Statistical differences between systems were significant for both years of study.

For content in ADF of natural meadow, mean values were between $30.07 \%$ and $31.04 \%$ for the samples gathered from ecological system and between $25.70 \%$ and $26.31 \%$ for the ones gathered from conventional system, statistical differences between those two systems being significant.

Content in ADF of alfalfa was situated under the minimal value of variation limit of $28 \%$ and $35 \%$ [70]. Statistical differences between those two systems for this parameter were insignificant for both years of study.

Content in $\mathrm{Ca}$ of natural meadow, with mean values both for the samples gathered from conventional system $(0.59 \%$ and $0.56 \%)$ as well as for the ones gathered from ecological system $(0.69 \%$ and $0.70 \%)$ were between the limits of $0.65 \%$ [52, 65] and $0.92 \%$ [66], statistical differences being distinct significant for $1^{\text {st }}$ year and very significant for $2^{\text {nd }}$ year.

Values for content of natural meadow in $\mathrm{P}$ were of $0.30 \%$ and $0.27 \%$ for samples gathered from conventional system, being slightly under the minimal value of the interval founded in literature, while values of $0.36 \%$ and $0.38 \%$ for samples gathered from ecological system were between variation limits of $0.35 \%$ [52,65] and $0.39 \%$ [66]. Statistical differences between those two systems were distinct significant in $1^{\text {st }}$ year and very significant in $2^{\text {nd }}$ year.

Content in Ca of green mass alfalfa before budding for samples gathered from ecological system were above superior limit founded in literature, $0.40 \%$ [67] and $1.65 \%$ [65]. The mean values for 
samples gathered from conventional system were between the above-mentioned limits, and statistical differences between those two systems were very significant for both analysed years.

Mean values determined for P content of green mass alfalfa for samples gathered from ecological system were a little bit lower than the minimal value of the interval founded in literature, while the ones gathered from conventional system, were placed into variation limits of $0.26 \%$ [70] and $0.75 \%$ [67]. The founded statistical differences between those two systems, for this parameter, were significant for both years of study.

All the mean values obtained for concentration of natural meadow and alfalfa in toxic heavy metals ( $\mathrm{Pb}$ and $\mathrm{Cd}$ ) were under the maximal limit imposed by Reg. EU, 1275/2013 (30 mg Pb/kg and 1 $\mathrm{mg} \mathrm{Cd} / \mathrm{kg}$ fodder with $12 \%$ moisture). The obtained results together with statistical significance of differences between founded concentrations into samples gathered from those two production systems are presented in Table 2.

Table 2. Results on the heavy metal content of organic and conventional forages

\begin{tabular}{|c|c|c|c|c|c|c|c|c|c|c|}
\hline \multirow{3}{*}{\multicolumn{2}{|c|}{ Specification }} & \multirow{3}{*}{$\mathrm{n}$} & \multicolumn{4}{|c|}{ Natural grassland } & \multicolumn{4}{|c|}{ Green alfalfa } \\
\hline & & & \multicolumn{2}{|c|}{$1^{\text {st }}$ year } & \multicolumn{2}{|l|}{$2^{\text {nd }}$ year } & \multicolumn{2}{|l|}{$1^{\text {st }}$ year } & \multicolumn{2}{|l|}{$2^{\text {nd }}$ year } \\
\hline & & & $\mathrm{X} \pm \mathrm{s}_{\mathrm{x}}$ & $\mathrm{V} \%$ & $\mathrm{X} \pm \mathrm{s}_{\mathrm{x}}$ & $\mathrm{V} \%$ & $\mathrm{X} \pm \mathrm{s}_{\mathrm{X}}$ & $\mathrm{V} \%$ & $\mathrm{X} \pm \mathrm{s}_{\mathrm{x}}$ & $\mathrm{V} \%$ \\
\hline \multirow{2}{*}{$\begin{array}{c}\mathrm{Pb} \mathrm{mg} / \mathrm{kg} \text { at } 12 \% \\
\text { moisture }\end{array}$} & Conv. & 5 & $0.06 \pm 0.004^{\mathrm{a}}$ & 13.33 & $0.09 \pm 0.007^{\mathrm{a}}$ & 16.67 & $0.12 \pm 0.004^{\mathrm{a}}$ & 6.67 & $0.16 \pm 0.005^{\mathrm{a}}$ & 7.63 \\
\hline & Eco. & 5 & $0.08 \pm 0.003^{\mathrm{c}}$ & 8.75 & $0.12 \pm 0.006^{\mathrm{c}}$ & 10.83 & $0.08 \pm 0.004^{\mathrm{d}}$ & 11.2 & $0.09 \pm 0.007^{\mathrm{d}}$ & 16.67 \\
\hline \multirow{2}{*}{$\begin{array}{l}\mathrm{Cd} \mathrm{mg/kg} \mathrm{at} \\
12 \% \text { moisture }\end{array}$} & Conv. & 5 & $0.018 \pm 0.001^{\mathrm{a}}$ & 11.11 & $0.012 \pm 0.001^{\mathrm{a}}$ & 13.33 & $0.019 \pm 0.001^{\mathrm{a}}$ & 8.95 & $0.02 \pm 0.001^{\mathrm{a}}$ & 11.50 \\
\hline & Eco. & 5 & $0.007 \pm 0.0004^{\mathrm{d}}$ & 14.29 & $0.01 \pm 0.001^{\mathrm{a}}$ & 12.00 & $0.01 \pm 0.001^{\mathrm{d}}$ & 17.0 & $0.013 \pm 0.001^{\mathrm{d}}$ & 17.81 \\
\hline \multirow{2}{*}{$\begin{array}{c}\mathrm{Cu} \\
\mathrm{mg} / \mathrm{kg} \mathrm{DM}\end{array}$} & Conv. & 5 & $1.16 \pm 0.036^{\mathrm{a}}$ & 6.90 & $1.25 \pm 0.068^{\mathrm{a}}$ & 12.16 & $1.23 \pm 0.013^{\mathrm{a}}$ & 2.44 & $1.26 \pm 0.055^{\mathrm{a}}$ & 9.77 \\
\hline & Eco. & 5 & $2.04 \pm 0.045^{\mathrm{d}}$ & 4.90 & $2.21 \pm 0.071^{\mathrm{d}}$ & 7.15 & $1.09 \pm 0.009^{\mathrm{d}}$ & 1.83 & $1.81 \pm 0.057^{\mathrm{d}}$ & 7.08 \\
\hline \multirow{2}{*}{$\begin{array}{c}\mathrm{Zn} \\
\mathrm{mg} / \mathrm{kg} \mathrm{DM}\end{array}$} & Conv. & 5 & $3.267 \pm 0.085^{\mathrm{a}}$ & 5.82 & $3.065 \pm 0.101^{\mathrm{a}}$ & 7.36 & $3.276 \pm 0.118^{\mathrm{a}}$ & 8,08 & $3.02 \pm 0.085^{\mathrm{a}}$ & 5.32 \\
\hline & Eco. & 5 & $3.045 \pm 0.118^{\mathrm{a}}$ & 8.69 & $2.953 \pm 0.110^{\mathrm{a}}$ & 8.32 & $3.646 \pm 0.110^{\mathrm{d}}$ & 6.74 & $3.345 \pm 0.08^{b}$ & 6.29 \\
\hline
\end{tabular}

For $\mathrm{Pb}$ concentration of natural meadow, mean values were under the limit presented in literature $2.49 \mathrm{mg} \mathrm{Pb} / \mathrm{kg} \mathrm{DM} \mathrm{[71]} \mathrm{and} 6.4 \mathrm{mg} \mathrm{Pb} / \mathrm{kg} \mathrm{DM}$ [72]. Statistical differences between those two production systems were distinct significant for both research years.

For concentration in $\mathrm{Cd}$ of samples from analysed natural meadow, the majority of established mean values were under the limit founded in literature, exception being samples gathered from conventional in $1^{\text {st }}$ year, which were placed into interval 4.3-15.7 $\mathrm{mg} \mathrm{Cd} / \mathrm{kg} \mathrm{DM}$ [73]. Statistical differences between those two systems, for this parameter, were very significant for both research years.

For concentration in $\mathrm{Zn}$ of natural meadow the recorded differences between those two systems were insignificant from statistical point of view.

Higher content in $\mathrm{Pb}$ of the analysed samples from ecological system could be explained by the fact that the meadow from which samples were gathered is transited by national road DN 282. Higher $\mathrm{Cu}$ concentration in analysed samples from ecological system could be explained by the reduced growing rate of plants. Banning of utilization of fertilizers based on phosphates (the main contamination source with $\mathrm{Cd}$ ) in the frame of ecological production system could explain the lower rate of $\mathrm{Cd}$ into analysed samples from this system.

The established mean values for $\mathrm{Pb}$ concentration of green mass alfalfa were under the limits presented in literature $0.198 \mathrm{mg} \mathrm{Pb} / \mathrm{kg} \mathrm{DM} \mathrm{[74]} \mathrm{and} 0.433 \mathrm{mg} \mathrm{Pb} / \mathrm{kg} \mathrm{SU}$ [75], statistical differences between production systems being very significant in both research years.

Concentration in $\mathrm{Cd}$ of green mass alfalfa analysed samples, had mean values placed under the limit of $0.045 \mathrm{mg} \mathrm{Cd} / \mathrm{kg} \mathrm{DM} \mathrm{[75]} \mathrm{and} 0.328 \mathrm{mg} \mathrm{Cd} \mathrm{kg} \mathrm{SU} \mathrm{[76].} \mathrm{Statistical} \mathrm{differences} \mathrm{between} \mathrm{those}$ two systems were very significant for both years of study.

For concentration in $\mathrm{Cu}$ and $\mathrm{Zn}$, statistical differences between those two systems were very significant.

Content in nitrates and nitrites of natural meadow and ecological alfalfa recorded values 
significant, statistically speaking; lower than samples gathered from conventional system.

Totality of analysed samples, for both research years, for nitrites content of those two forages (Table 3), were situated under the maximum admissible limit of $15 \mathrm{ppm} \mathrm{NO}_{2}^{-}$fodder with $12 \%$ moisture, and imposed by Regulation 575/2011.

Concentration in nitrites $\left(\mathrm{NO}_{2}^{-}\right)$of natural meadow had mean values between 1.56 and $1.90 \mathrm{ppm}$ at $12 \%$ moisture, for conventional production system and between 1.78 and $1.55 \mathrm{ppm}$ for the ecological production system.

Table 3. Nitrate and nitrite content of organic and conventional forages

\begin{tabular}{|c|c|c|c|c|c|c|c|c|c|c|}
\hline \multirow{3}{*}{ Specification } & & \multirow{3}{*}{$\mathrm{n}$} & \multicolumn{4}{|c|}{ Natural grassland } & \multicolumn{4}{|c|}{ Green alfalfa } \\
\hline & & & \multicolumn{2}{|c|}{$1^{\text {st }}$ year } & \multicolumn{2}{|c|}{$2^{\text {nd }}$ year } & \multicolumn{2}{|l|}{$1^{\text {st }}$ year } & \multicolumn{2}{|c|}{$2^{\text {nd }}$ year } \\
\hline & & & $\mathrm{X} \pm \mathrm{s}_{\mathrm{x}}$ & $\mathrm{V} \%$ & $\mathrm{X} \pm \mathrm{s}_{\mathrm{x}}$ & $\mathrm{V} \%$ & $\mathrm{X} \pm \mathrm{s}_{\mathrm{x}}$ & $\mathrm{V} \%$ & $\mathrm{X} \pm \mathrm{s}_{\mathrm{x}}$ & V\% \\
\hline \multirow{2}{*}{$\mathrm{NO}_{3}^{-} \mathrm{ppm}$} & Conv. & 5 & $50.63 \pm 0.59^{\mathrm{a}}$ & 2.62 & $49.31 \pm 1.37^{\mathrm{a}}$ & 6.21 & $384.92 \pm 8.10^{\mathrm{a}}$ & 4.71 & $395.54 \pm 7.92^{\mathrm{a}}$ & 4.48 \\
\hline & Eco. & 5 & $47.44 \pm 0.89^{c}$ & 4.21 & $43.31 \pm 1.39^{b}$ & 7.15 & $108.32 \pm 2.02^{\mathrm{d}}$ & 4.11 & $117.33 \pm 2.38^{\mathrm{d}}$ & 4.61 \\
\hline \multirow{2}{*}{$\begin{array}{l}\mathrm{NO}_{2}-\mathrm{ppm} \text { at } 12 \% \\
\text { fodder moisture }\end{array}$} & Conv. & 5 & $1.56 \pm 0.05^{\mathrm{a}}$ & 7.51 & $1.90 \pm 0.16^{\mathrm{a}}$ & 19.42 & $5.02 \pm 0.21^{\mathrm{a}}$ & 9.51 & $4.98 \pm 0.07^{\mathrm{a}}$ & 3.20 \\
\hline & Eco. & 5 & $1.78 \pm 0.05^{\mathrm{b}}$ & 6.60 & $1.55 \pm 0.15^{\mathrm{a}}$ & 21.7 & $1.46 \pm 0.04^{\mathrm{d}}$ & 5.79 & $1.58 \pm 0.05^{\mathrm{d}}$ & 7.21 \\
\hline
\end{tabular}

Different exponents for the same indicator and year, show significant differences for mono-factorial analysis of variance (ANOVA): $\mathrm{p} \leq 0.05$ for ${ }^{\mathrm{ab}}, \mathrm{p} \leq 0.01$ for ${ }^{\mathrm{ac}}, \mathrm{p} \leq 0.001$ for ${ }^{\text {ad }}$

Concentration in nitrites $\left(\mathrm{NO}_{2}^{-}\right)$of green mass alfalfa had mean values between 5.02 and 4.98 ppm at $12 \%$ moisture, for conventional system and $1.46-1.58 \mathrm{ppm}$ for ecological one, differences between systems being very significant.

Banning of utilization of fertilizers based on nitrogen in the frame of ecological production systems could explain the lower rate in these compounds of the analysed natural meadow belonging to this system.

Gas chromatographic analysis of concentration of organo-chlorinated and organo-phosphoric pesticides from samples of natural meadow and green mass alfalfa gathered from both systems, conventional and ecological, highlight the fact that pesticides residuum was under the detection limit of $0.05 \mathrm{mg} / \mathrm{kg} \mathrm{DM}$ for organo-chlorinated pesticides and $0.001 \mathrm{mg} / \mathrm{kg}$ for organo-phosphoric pesticides.

\section{Conclusions}

Chemical composition of natural meadow and green mass alfalfa oscillated function of production system, for majority of studied indicators values being significant different in the favour of ecological system. Exceptions were content in crude fat and NES for both forages.

Agro-technical and climatic conditions from those 2 years of study also contributed to obtaining of different values. Knowing these differences is very useful for establishing the nutritive value of each fodder as well as for establishing the daily ration.

The relevant indicators under ecological aspect (content in heavy metals, pesticides, nitrites and nitrates) show that analysed and utilised forages for cows' nourishment to obtain ecological milk were into the quality parameters imposed by this system.

\section{References}

1. Alothman, M., HOGAN, S.A., HENnESSY, D., DILlON, P., KILCAWLEY, K.N., DONOVAN, M., TOBIN, J., FENELON, M.A., O'CALLAGHAN, T.F., The "grass-fed" milk story: understanding the impact of pasture feeding on the composition and quality of bovine milk, Foods, 8(350), 2019, 1-24.

2. GIVENS, D.I., The role of animal nutrition in improving the nutritive value of animal-derived foods in relation to chronic disease, Proc. Nutr. Soc., 64, 2007, 395-402.

3. DROR, D.K., ALLEN, L.H., The importance of milk and other animal-source foods for children in low-income countries, Food and Nutrition Bulletin, 32(3), 2011, 227-243. 
4. WILEY, A.S., Doe's milk makes children grow? Relationships between milk consumption and height in NHANES 1999-2002, American Journal of Human Biology, 17(4), 2004, 425-441.

5. COMMISSION REGULATION (EC) No 889/2008 of 5 September 2008 laying down detailed rules for the implementation of Council Regulation (EC) No 834/2007 on organic production and labelling of organic products with regard to organic production, labelling and control.

6. KATAYAMA, N., OSADA, Y., Organic farming and associated management practices benefit multiple wild life taxa: A large-scale field study in rice paddy landscapes, Journal of Applied Ecology, 56(8), 2019, 1970-1981.

7. LIAO, J., XU, Q., XU, H., HUANG, D., Natural farming improves soil quality and alters microbial diversity in a cabbage field in japan, Sustainability, 11(11), 2019, 1-16.

8. PINTILIE, O., ANDRIES, C., COSMA, A., ZAHARIA, M., DROCHIOIU, G., VASILACHE, V., SANDU, I., The influence of dinitro phenolic pesticides on the viability of plants, Rev. Chim. (Bucharest), 66(9), 2015, 1321-1326.

9. RASLAN, A., ELBADRY, S., DARWISH, W.S., Estimation and human health risk assessment of organochlorine pesticides in raw milk marketed in Zagazig city, Egypt, Journal of Toxicology, 2018, $1-8$.

10. HAARSTAD, K., BAVOR, J., ROSETH, R., Pesticides in greenhouse runoff, soil and plants: a screening. Env. \& Biol. Monit. J., 5(1), 2012, 1-13.

11. NEAMTU, S., BORS, A.M., STEFAN, S., Risk assessment of some persistent organic pollutants on environment and health, Rev. Chim. (Bucharest), 58(9), 2007, 938-942.

12. LAPIERRE, L., QUINTREL, M., LAGOS-SUSAETA, F., HERVE-CLAUDE, L.P., RIQUELME, R., OVIEDO, P., MAINO, M., CORNEJO, J., Assessment of antimicrobial and pesticide residues in food products sourced from peasant family farming in Chile, Journal Food Prot., 82(9), 2019, 15831590.

13. AYDIN, S., AYDIN, M.E., BEDUK, F., ULVI, A., Organohalogenated pollutants in raw and UHT cow's milk from Turkey: a risk assessment of dietary intake, Environ. Sci. Pollut. Res. Int., 26(13), 2019, 12788-12797.

14. MICLEAN, M., CADAR, O., LEVEI, E.A., TODEA, D.A., Human health risk assessment of organochlorine compounds associated with raw milk consumption in a Romanian industrial area, Italian Journal of Food Science, 30(1), 2018, 116-127.

15. MEMON, Q.U., WAGAN, S.A., DONG, C., XIAO, S., LUAN, J., DAMALAS, C.A., Health problems from pesticide exposure and personal protective measures among women cotton workers in southern Pakistan, Sci. Total Env., 685, 2019, 659-666.

16. KIM, S.K., PARK, S., CHANG, S.J., KIM, S.K., SONG, J.S., KIM, H.R., OH, S.S., KOH, S.B., Pesticides as a risk factor for metabolic syndrome: Population-based longitudinal study in Korea, Molecular \& Cellular Toxicology, 15(4), 2019, 431-444.

17. KI-HYUN, K., EHSANUL, K., SHAMIN, A.J., Exposure to pesticides and the associated human health effects, Sci. Total Env., 575, 2017, 525-535.

18. BENBROOK, C., BAKER, B., Perspective on dietary risk assessment of pesticide residues in organic food, Sustainability, 6(6), 2014, 3552-3570.

19. SREDNICKA-TODER, D., BARANSKI, M., SEAL, C., SANDERSON, R., Higher PUFA and n-3 PUFA, conjugated linoleic acid, alpha-tocopherol and iron, but lower iodine and selenium concentrations in organic milk: a systematic literature review and meta and redundancy analyses, British J. of Nutr., 115(6), 2016, 1043-1060.

20. AVKOPASHVILI, G., AVKOPASHVILI, M., GONGADZE, A., TSULUKIDZE, M., SHENGELIA, E., Determination of $\mathrm{Cu}, \mathrm{Zn}$ and $\mathrm{Cd}$ in soil, water and food products in the vicinity of RMG gold and copper mine, Kazreti, Georgia, Annals of Agrarian Science, 15(2), 2017, 269-272.

21. AnAStasis, C., Christodoulos, T., COSTAS, C., IOANNIS, K.K., SOTERIOS, P., Assessment of toxic heavy metals concentrations in soils and wild and cultivated plant species in Limni abandoned copper mining site, Cyprus, Journal of Geochemical Exploration, 178, 2017, 16-22. 
22. CASTRO, N.P., CALDERON, F., PEREZ, M., SONI, E., REYES, E., Health risk due to chronic heavy metal consumption via cow's milk produced in Puebla, Mexico, in irrigated wastewater areas, Food Add. Cont., 12(1), 2019, 38-44.

23. AIOANEI, N., POP, I.M., Heavy metal and pesticide contamination of maize silage derived from two different production systems (conventional and organic), Current Opinion in Biotechnology, 24, Suppl. 1, 2013, S86.

24. CRISTE, R.D., UNTEA, A.E., OLTEANU, M., RADUTOIU, D., VLADESCU, L., Heavy metals accumulation in some plants of spontaneous flora in correlation with soil composition, Rev. Chim. (Bucharest), 64(3), 2013, 225-232.

25. MICLEAN, M., LEVEI, E.A., SENILA, M., ROMAN, C., CORDOS, E.A., Assessment of Cu, Pb, $\mathrm{Zn}$ and $\mathrm{Cd}$ availability to vegetable species grown in the vicinity of tailing deposits from Baia Mare area, Rev. Chim. (Bucharest), 60(1), 2009, 1-4.

26. ALBU, A., POPESCU, O., TARCA, F., POP, C., POP, I.M., Copper and zinc content in dairy cow feeds, Scientific Papers, USAMV Iasi, Veterinary Medicine Series, 51(10), 2008, 3-7.

27. GOUGOULIAS, N., LEONTOPOULOS, S., MAKRIDIS, C.H., Influence of food allowance in heavy metal's concentration in raw milk production of several feed animals, Emirates Journal of Food and Agriculture, 26(9), 2014, 828-834.

28. KHAN, Z.I., UGULU, I., UMAR, S., AHMAD, K., MEHMOOD, N., ASHFAQ, A., BASHIR, H., SOHAIL, M., Potential toxic metal accumulation in soil, forage and blood plasma of buffaloes sampled from Jhang, Pakistan, Bull. Environ. Contam. Toxicol., 101(2), 2018, 235-242.

29. JARUP, L., Hazards of heavy metal contamination, Br. Med. Bull., 68, 2003, 167-173.

30. COON, S., STARK, A., PETERSON, E., GLOI, A., KORTSHA, G., POUNDS, J., Whole-body lifetime occupational lead exposure and risk of Parkinson's disease, J. Environ. Health Perspect., 114(12), 2006, 1872-1876.

31. HOUGH, R.L., BREWARD, N., YOUNG, S.D., CROUT, N.M., TYE, A.M., MOIR, A.M., Assessing potential risk of heavy metal exposure from consumption of home-produced vegetables by urban populations, Environ. Health Perspect., 112(5), 2004, 215-221.

32. REMBIALKOWSKA, E., Quality of plant products from organic agriculture, J. Sci. Food Agric., 87, 2007, 2757-2762.

33. LESTER, E.G., Organic versus conventionally grown produce: quality differences and guidelines for comparison studies, Hort. Science, 41(2), 2006, 296-300.

34. REMBIALKOWSKA, E., The impact of organic agriculture on food quality, Agricultura, 3, 2004, 19-26.

35. WORTHINGTON, V., Nutritional quality of organic versus conventional fruits, vegetable and grains, The J. of Alternative and Complementary Med., 7(2), 2001, 161-173.

36. DANGOUR, A.D., DODHIA, S.K., HAYTER, A., ALLEN, E., LOCK, K., UAUY, R., Nutritional quality of organic foods: a systematic review, Am. J. Clin. Nutr., 90, 2009, 680-691.

37. ***, SR EN ISO 6497:2005, Fodders. Sampling

38. ***, SR ISO 6498:2001, Fodders. Samples preparation for analysis

39.***, SR ISO 6496:2001, Fodders. Determination of humidity content and other volatile substances.

40. DOLIS, M.G., BOISTEANU, P.C., SIMEANU, D., Research regarding apparent digestibility of selected hybrid mulberry leaf chemical content, Rev. Chim. (Bucharest), 68(6), 2017, 1361-1366.

41.***, SR ISO 712:2010, Cereals and cereal products. Determination of humidity (Practical reference method).

42. DOLIS, M.G., BOISTEANU, P.C., USTUROI, M.G., SIMEANU, D., BODESCU, D., NACU, G., USTUROI, A., SIMEANU, C., Research on digestibility of the mulberry leaf from the Kokuso 21 variety in relation to the dynamics of the chemical content, Rev. Chim. (Bucharest), 69(2), 2018, 439444.

43.***, SR EN ISO 2171:2010, Cereals, vegetables and derived product. Determination of ash content by calcinations. 
44. *** ASSOCIATION OF OFFICIAL ANALYTICAL CHEMISTS. Ash of Animal Feed (942.05). Official methods of analysis, $1990,15^{\text {th }}$ edition, 70 .

45. DOLIS, M.G., MORARU, R.A., SIMEANU, C., SANDU, I., BODESCU, D., VINTILA, V., Contributions at capitalization study on chemical content from mulberry tree leave by Bombyx mori larvae, Rev. Chim. (Bucharest), 70(10), 2019, 3681-3686.

46. $* * *$ SR EN ISO 5983-1: 2006/AC:2009, Fodders. Determination of nitrogen content and calculation of crude protein content. Part 1: The Kjeldahl method.

47. SIMEANU, C., SIMEANU, D., POPA, A., USTUROI, A., BODESCU, D., DOLIS, M.G., Research regarding content in amino-acids and biological value of proteins from Polyodon spathula sturgeon meat, Rev. Chim. (Bucharest), 68(5), 2017, 1063-1069.

48. *** SR ISO 6492: 2001. Fodders. Determination of fat content.

49. USTUROI, A., SIMEANU, C., USTUROI, M.G., DOLIS, M.G., RATU, R.N., SIMEANU, D., Influence of packaging type on the dynamics of powdered eggs chemical composition, Mat. Plast., 54(2), 2017, 380-385.

50. $* * *$ SR EN ISO 6865:2002, Fodders. Determination of crude fibre content. Method with intermediate filtration

51. SIMEANU, C., SIMEANU, D., DOLIS, M.G., Effect of dietary crude fibber level on the development of reproductive system in rabbits, Research J. of Biotech., 12(2), 2017, 7-14.

52. POP, I.M., HALGA, P., AVARVAREI, T., Nutrition and nourishment of animals (in Romanian), Ed. Tipo Moldova, Iasi, 2006.

53. SIMEANU, D., Nutrition and nourishment of animals (in Romanian), Ed. Ion Ionescu de la Brad, Iasi, 2018.

54. DOLIS, M.G., SIMEANU, C., USTUROI, A., SIMEANU, D., Research regarding chemical composition and the digestibility of the mulberry leaves from Eforie variety, Rev. Chim. (Bucharest), 68(1), 2017, 151-156.

55. *** SR EN ISO 16472:2006, Fodders. Determination of fibre content by treating with amylase and neutral detergent.

56. *** SR EN ISO 13906:2008, Fodders. Determination of acid fibre detergent content (ADF) and sulphuric lignine (ADL).

57. ALBU, A., POP, I.M., RADU-RUSU, C., Calcium (Ca) and phosphorus (P) concentration in dairy cow feeds, Scientific Papers, Anim. Sci. Series, 57(17), 2012, 70-74.

58. SIMEANU, C., PASARIN, B., BOISTEANU, P.C., SIMEANU, D., DOLIS, M.G., NACU, G., IGNAT, G., HOHA, G.V., Sensorial, physico-chemical and nutritive characterization of paddlefish (Polyodon spathula) meat, Rev. Chim. (Bucharest), 69(10), 2018, 2837-2844.

59. *** SR EN ISO 6869:2002, Fodders. Determination of calcium, copper, iron, magnesium, manganese, potassium, sodium and zinc content. Atomic absorption spectrometry method.

60. *** SR EN ISO 14082:2003, Foodstuffs. Determination of microelements. Determination of lead, cadmium, zinc, copper, iron and chromium by atomic absorption spectrometry (AAS) after calcinations.

61. NACU, G., BOlOGA, M., POP, C., BOISTEANU, P.C., SIMEANU, D., DOLIS, M.G., DONOSA, R., Research on chemical composition and nutritive value of green fodder used in ecological production of eggs for consumption, Rev. Chim. (Bucharest), 69(3), 2018, 682-687.

62. *** SR EN ISO 14181:2001, Fodders. Determination of organo-chlorine pesticide residues. Gas chromatographic method.

63. *** SR EN ISO 14182:2001, Fodders. Determination of organo-phosphorus pesticide residues. Gas chromatographic method.

64. *** SR 13175:1993, Fodders. Determination of nitrites and nitrates content.

65. JARRIGE, R., DEMARQUILLY, C., DULPHY, J.P., HODEN, A., ROBELIN, J., BERANGER, C., GEAY, Y., JOURNET, M., MICOL, D., PETIT, M., The INRA Fill Unit System for predicting the voluntary intake of forage-based diets in ruminants - A Review, J. Anim. Sci., 63(6), 1986, 1737-1758. 
66. BURlaCU, GH., CAVACHE, A., BURLACU, R., Productive potential of fodders and their usage (in Romanian), Ed. Ceres, Bucuresti, 2002.

67. POP, I.M., RADU-RUSU, C., SIMEANU, D., ALBU, A., POPA, V., Characterization of the nutritional value of alfalfa harvested at different stages of vegetation using cell walls content-based methods, Scientific Papers, Animal Science series, 53, 2010, 190-194.

68. KAYA, I., NCUER, A., UNAL, I., Nutritive value of pastures in Cars District I. Botanical and nutrient composition at different stages of maturity, Turk J. Vet. Anim. Sci., 28, 2004, 275-280.

69. AVCI, M., KAPLAN, O., YERTURK, M., ASLAN, M., Nutrient and botanical composition of pasture in Ceylsnpinar agriculture farm, Vet. Fac. Derg., 17(1-2), 2006, 9-13.

70. PRESTON, R.L., What's the feed composition value of that cattle feed?, Beef Magazine, 2010.

71. VON SOTHEN, F., Heavy metal input on farmland - an indicator for a sustainable agricultural system, Ed. Shaker Verlag, Germany, 10, 2001, 363-369.

72. BIANU, E., NICA, D., Monitoring the effect of cadmium on birds in an area heavily polluted with heavy metals, Scientific papers USAMVB Timisoara, Serie C, XLVI-XLVII, 2003-2004, 514-520.

73. MILOS, M., DRINCEANU, D., Mineral nutrition of animals (in Romanian), Ed. Ceres, Bucuresti, 1980.

74. LI, Y., MCROY, D.F., POWEL, J., SAAM, M.H., JACKSON-SMITH, D., A servery of selected heavy metal concentrations in Wisconsin dairy feeds, J. Dairy Sci., 88, 2008, 2911-2922.

75. TRINCA, L.C., VOLF, M., AVARVAREI, I., BIANU, E., Pb, Cd and Se levels in fodder plants as part of „farm to fork" food chain survey in Iasi area, Scientific Papers, USAMV Iasi, Veterinary Medicine Series, 51(10), 2008, 192-196.

76. ALBU, A., TARCA, F., POP, I.M., Evaluation of heavy metals (lead and cadmium) content in feeds from Moldavian area, using atomic absorption spectrophotometry method, Scientific Papers USAMV Iasi, Animal Science Series, 50(12), 2007, 402-407.

Manuscript received: 6.03 .2020 